\title{
Lead exposure among young urban women
}

\author{
Jacqueline M. Moline, M.D., ${ }^{(1)}$ M.Sc, Anne L. Golden, Ph.D., ${ }^{(1)}$ Andrew C.Todd, Ph.D., ${ }^{(1)}$
}

James H. Godbold, Ph.D.,(1) Gertrud S. Berkowitz, Ph.D.1)

\section{Moline JM, Golden AL, Todd AC, Godbold JH, Berkowitz GS. Lead exposure among young urban women. Salud Publica Mex 1999;41 suppl 2:S82-S87.}

\begin{abstract}
A bstract
Objective. Blood lead levels have declined among every age group in the United States, but urban minority residents remain at disproportionate risk for elevated lead levels. 0 ur objective was to measure lead burden in young women of childbearing age in $\mathrm{N}$ ew York City. We also describe successful means of recruiting this population into a cohort study. Material and methods. Healthy women aged 18-25 attending a N ew York City health care center in 1995-1998 were eligible for participation. Participants were recruited by health care providers, the study coordinator and the participants themselves. Venous blood samples were obtained for whole blood lead, ferritin and hematocrit measurements, and detailed questionnaires were administered. Results. 239 women have been recruited to date. The population is predominately minority: $62 \%$ African-American, 33\% Hispanic and 5\% Caucasian/Asian. The average age of participants is 19.3 years. Recruitment of participants into the study is predominantly (55\%) through "word of mouth" from previously enrolled participants. Few participants learned of the study through their health care providers. The mean blood lead level among study participants is $2.1 \pm 1.7 \mu \mathrm{g} / \mathrm{dl}$, which is consistent with the most recent United States national survey. Conclusions. Blood lead levels are low in young, urban minority women of childbearing age in $\mathrm{N}$ ew York City. In this population, recruitment efforts were substantially enhanced with the help of enrolled participants and the health care community.
\end{abstract}

Key words: lead; women; urban po pulation; environmental exposure; minority groups; U nited States

\author{
Moline JM, Golden AL, Todd AC, \\ Godbold JH, Berkowitz GS. \\ Exposición a plomo en mujeres jóvenes \\ residentes en zonas urbanas. \\ Salud Publica Mex 1999;41 supl 2:S82-S87.
}

\section{Resumen}

Objetivo. En Estados U nidos, los niveles de plomo en sangre han declinado en todos los grupos de edad; no obstante, los grupos mino ritarios que residen en áreas urbanas tienen un riesgo muy alto de poseer niveles elevados de dicho metal. N uestro objetivo fue medir el nivel de plomo en mujeres jóvenes, en edad reproductiva, en la ciudad de N ueva York. También se describe el éxito en el reclutamiento de esa población para participar en un estudio de cohorte. Material y métodos. Las mujeres elegibles fueron aquellas que acudieron al centro de salud de la ciudad de N ueva York durante 1995-1998, tenían entre 18 y 25 años de edad y estaban sanas. El reclutamiento se llevó a cabo por los proveedores de salud, el coordinador del estudio y las mismas mujeres. Se administraron cuestionarios detallados y se obtuvieron muestras sanguíneas en donde se determinaron los niveles de plomo en sangre total, ferritina y hemato crito. ResultadosA la fecha se han reclutado 239 mujeres. La población es predominantemente de grupos minoritarios: $62 \%$ africanas-americanas, $33 \%$ hispánicas y $5 \%$ caucásicas-asiáticas. El promedio de edad es de 19.3 años. El reclutamiento de las participantes se hace invitando a las mujeres que previamente han aceptado participar en el estudio (55\%). Algunas se enteraron del estudio por los proveedores de salud. El nivel medio de plomo fue de $2.1 \pm 1.7$ $\mu \mathrm{g} / \mathrm{dl}$, el cual es consistente con las encuestas nacionales más recientes de Estados Unidos. Conclusiones. Los niveles de plomo en sangre son bajos en mujeres de grupos minoritarios, jóvenes, en edad reproductiva, que residen en zonas urbanas de la ciudad de N uevaYork. En esta población el reclutamiento se incrementó sustancialmente con la ayuda de las participantes y la comunidad de proveedores de salud.

Palabras clave: plomo; mujeres; po blación urbana; exposición a riesgos ambientales; grupos minoritarios; Estados Unidos

(1) Department of Community and Preventive Medicine, Mount Sinai School of Medicine, N ew York, N ew York, United States of America.

Recibed on: June 3,1998 • Accepted on: March 3, 1999

Reprint requests to: Jacqueline Moline, MD, MSc. The Mount Sinai School of Medicine. Box 1057. 0 ne Gustave Levy Place. $\mathrm{N}$ ew York, $\mathrm{N}$ ew York 10029, United States of America. E-mail: jacqueline.moline@ mountsinai.org 
$E$ nvironmental exposure to lead is ubiquitous in industrialized societies. ${ }^{1}$ Lead is not an essential element, has no known biological significance and can exert toxic effects on a number of organ systems. The most vulnerable population for lead's adverse health includes the developing fetus and young children. Lead freely crosses the placenta, providing the sole source of lead exposure for the fetus, ${ }^{2}$ and can thus exert a deleterious effect on the fetus. There is growing evidence that relatively low levels of environmental lead exposure and cumulative body burdens of lead may be associated with adverse pregnancy outcomes, as well as behavioral dysfunction and delayed motor development among children. ${ }^{3-5}$ Bellinger et al., ${ }^{4}$ found that decrements in intelligence and slowed development were significantly associated with higher umbilical cord blood lead levels, even though the levels were well below $25 \mu \mathrm{g} / \mathrm{dl}$.

In the United States over the past twenty years, blood lead levels have decreased significantly, primarily as a result of the removal of lead from gasoline. Yet, disproportionately higher numbers of elevated blood lead levels are found in urban minority residents across all socioeconomic levels, an observation that has been evident for many years. ${ }^{6,7}$ This elevated incidence in the minorities may be because low income and minority status are associated with living in older or deteriorating housing, or in an area with a high prevalence of lead-contaminated soil and dust. ${ }^{8-10}$

An inverse relationship between body stores of iron and lead retention has been observed in both humans and animals. ${ }^{11,12}$ Iron-deficient children have been shown to absorb more lead than iron-replete children. The children manifest a higher fraction of blood lead in the plasma and in peripheral tissues, and also exhibit greater toxic responses for a given blood lead concentration. ${ }^{13}$ Graziano et al. ${ }^{14}$ found that pregnant women with lower iron stores, as measured by serum ferritin levels, had significantly higher blood lead levels. Ferritin levels reflect body iron stores and are minimally affected by transient or environmental factors. ${ }^{14,15}$

Once absorbed, lead is distributed in the body in three main compartments: bone, soft tissue and blood. Traditional measures of lead include only one compartment, the blood, in which $99 \%$ of the lead is bound to red blood cells. The half-life of lead in blood is approximately 30 days. ${ }^{16}$ The plasma lead, i.e., circulating lead that is unbound to red blood cells, may be more biologically available and or relevant to target organ toxicity. ${ }^{17}$ The second compartment, soft tissue, where most of the adverse effects of lead occur, includes the kidney, brain, liver and bone marrow. The third, and largest compartment is the bone which represents an accumulating reservoir containing approximately $95 \%$ of the body burden of lead in adults. ${ }^{16,18}$ Thus blood lead, the clinical measure of lead that is most widely used to assess lead exposure reflects only a fraction of the body burden of lead; furthermore, it represents a fraction that has only recently been absorbed.

Questions persist about whether a significant amount of this skeletal lead is mobilized into the bloodstream during periods of high bone turnover such as pregnancy and lactation ${ }^{19}$, resulting in increased lead exposure to the fetus or breast-fed infant. In a prospective cohort study of young women residing in New York City, we are examining determinants of body burdens of lead resulting from current and cumulative exposure. The aim of this study is to assess whether body burden of lead changes as a result of pregnancy. In initial evaluations, we have assessed lead and iron stores in a cohort of women historically at highest risk for lead exposure. In this report, we present results of the baseline evaluations of blood lead and iron stores. We also describe methods used in the successful recruitment and retention of individuals from an urban minority population enrolled in the prospective study.

\section{Material and methods}

The components of the on-going prospective study include measurements of whole blood lead, bone lead (as measured by ${ }^{109} \mathrm{Cd}$-based $\mathrm{K}$-shell x-ray fluorescence), serum ferritin and hematocrit levels. Women aged 18-25 years are evaluated prior to pregnancy and at two postpartum visits. A comparison group of women who have undergone the baseline evaluation but who do not become pregnant have been matched to the pregnant women on age, race, and date of baseline evaluation. They are re-evaluated at the same time intervals as the women who become pregnant. The association between body burdens of lead and iron stores will be examined to determine whether the iron stores influence blood lead levels and bone lead levels and lead mobilization from bone in future analyses.

Healthy women aged 18-25 years who reside in the New York City metropolitan area are eligible for participation in the study. The primary source of study participants has been the Mount Sinai Medical Center Adolescent Health Center (AHC), which provides medical and reproductive health services, social work and health education services. The majority of the population seen at the AHC is adolescents (up to the age of 21) from ethnic minority groups who also come from socially disadvantaged backgrounds. 
Women are informed of the study by a number of different methods: by talking to health educators, nurses and physicians at the AHC; when approached by the study coordinator in the AHC waiting room; by reading posters describing the study; and by "wordof-mouth." Individuals who are interested in participating are asked to contact the study coordinator to undergo a screening questionnaire to determine eligibility.

Because the primary aim of the study is to determine whether body burdens of lead change as a result of pregnancy, only women who are currently sexually active are eligible to participate. Women who are pregnant or lactating at the time of recruitment are excluded. Other exclusion criteria include a history of chronic medical problems such as cancer or thyroid disease; medication use (e.g., corticosteroids) that may affect bone turnover; and the use of long-acting hormonal contraceptives such as DepoProvera ${ }^{\circledR}$ (Upjohn, Kalamazoo, Michigan), since they are unlikely to become pregnant.

Women who have already had children are eligible to participate; their inclusion will allow us, in the future, to determine whether lead burdens in nulliparous women differ from those in primiparous women.

Reminder telephone calls are made the day prior to a participant's scheduled appointment. Informed consent is obtained from all participants in accordance with the Mount Sinai Medical Center Institutional Review Board Guidelines. Following the evaluation, participants are also asked to discuss the study with potentially eligible friends and relatives who might be interested in participating. They are also asked to inform the study coordinator if they become pregnant. All participants are sent cards which thank them for their participation. These cards also confirm whether their mailing address information is correct. Participants also receive cards periodically, which remind them of the study and which ask for their continued participation if they become pregnant.

Blood lead is measured from venous blood specimens collected from the antecubital vein into tubes containing ethylene-diaminetetracetic acid (EDTA) anticoagulant. The analytical method for blood lead is that of Parsons ${ }^{20}$ and Miller et al. ${ }^{21}$ and uses matrix modifier-diluted (Triton $\mathrm{X}$ and ammonium phosphate in nitric acid) samples that are directly injected into the atomic absorption spectrophotometer (AAS). The AAS is a Perkin-Elmer 4100ZL instrument with graphite furnace with Zeeman correction for background interferences. The lead laboratory has been OSHA-certified since 1994. During 1997, the accuracy was within $5 \%$ or on average less than $0.2 \mu \mathrm{g} / \mathrm{dl}$ deviation from target values for 48 proficiency test samples across a wide range of values $(0-100 \mu \mathrm{g} / \mathrm{dl})$.

Hematocrit is measured using a pre-calibrated Read-A-Crit ${ }^{\circledR}$ (Clay-Adams, Parsippany, New Jersey) microcapillary tube and centrifuge system. The hematocrit is measured during the patient visit, giving the participant immediate feedback on their iron status; if a patient is found to be anemic, follow-up is recommended. Serum ferritin measurements are made with an automated Abbott (Dallas, Texas) Axsyn System high volume analyzer.

A questionnaire administered by the study coordinator obtains data on demographic characteristics, residential history, occupational and environmental lead exposure, reproductive history, medical history, medication use, and diet.

Statistical analyses incorporated Pearson's correlation coefficient to assess the relationship between two continuous variables, and analysis of variance to test for differences in the relationships among ethnic groups..$^{22}$ PROC CORR and PROC GLM ${ }^{23}$ in the SAS ${ }^{\circledR}$ (SAS Institute, Cary, North Carolina) statistical software package was used for statistical analysis.

\section{Results}

To date, baseline evaluations have been completed on 239 women. The average age of the women at baseline is 19.3 years. Ethnicity is classified by self-report. Sixty-two percent of participants are African-American, 33\% are Hispanic and 5\% are Caucasian or Asian (Table I). Current New York City census data show that $25.7 \%$ and $23.8 \%$ of the population are African-American and Hispanic, respectively. ${ }^{24}$ Therefore, the participants in this study reflect the referral population that utilizes the AHC, not the general New York City population. ${ }^{\ddagger}$ As described, participants were recruited by different methods. Beginning in the second year of the study, statistics were kept on how patients learned of the study (Table II). More than half of the participants questioned (55\%) learned of the project from a friend or relative. While $32 \%$ learned of the study from AHC health educators, only $1 \%$ of participants were directly recruited by physicians. No differences in lead or iron burdens were detected based how the participant learned of the study.

As shown in Table I, the levels of blood lead among study participants are quite low, with an overall mean of $2.1 \mu \mathrm{g} / \mathrm{dl}$, and a standard deviation $\pm 1.7 \mu \mathrm{g} / \mathrm{dl}$, and

\footnotetext{
* Wolff, MS. Personal communication

‡ Díaz, A. Personal communication.
} 
no differences by ethnicity. These blood lead levels are similar to those observed in the most recent national survey in the United States, NHANES III, in which blood lead levels were $1.8 \mathrm{mg} / \mathrm{dl}$ for Non-Hispanic Blacks age 6-19 years, and $2.2 \mathrm{mg} / \mathrm{dl}$ for those age 20-49 years, and $1.0 \mu \mathrm{g} / \mathrm{dl}$ and $1.7 \mathrm{mg} / \mathrm{dl}$ for NonHispanic Whites age 6-19 and 20-49 years, respectively. ${ }^{6}$ Although several studies such as those by Pirkle ${ }^{25}$ and Kurtin ${ }^{26}$ have found that African-Americans have higher blood lead levels than Hispanics or Caucasians, our data do not show this difference.

The hematocrit level among in African-American women, 0.386 , is significantly lower than the level in Hispanic women, 0.395 and Caucasian women, 0.400,

Table 1

Age, Lead and Iron LeVels, by Ethnicity, among Study Participants. New York City, 1995-1998

\begin{tabular}{|c|c|c|c|c|c|}
\hline Race & $\begin{array}{c}N \\
(\%)\end{array}$ & $\begin{array}{l}\text { Mean } \\
\text { age } \\
\text { (SD) (yrs) }\end{array}$ & $\begin{array}{c}\text { Mean } \\
\text { blood } \mathrm{Pb} \\
(\mathrm{SD})(\mu \mathrm{g} / \mathrm{dl})\end{array}$ & $\begin{array}{c}\text { M ean } \\
\text { ferritin } \\
(S D)(n g / m l)^{*}\end{array}$ & $\begin{array}{c}\text { M ean } \\
\text { hematocrit } \\
\text { (SD) }\end{array}$ \\
\hline \multirow[t]{2}{*}{ African - American } & 148 & 20.1 & 2.2 & 31.9 & $.386^{\ddagger}$ \\
\hline & (62) & $(2.3)$ & (1.7) & $(25.5)$ & $(.022)$ \\
\hline \multirow[t]{2}{*}{ Hispanic } & 79 & 19.9 & 2.0 & 35.5 & .395 \\
\hline & (33) & $(1.5)$ & (1.7) & $(30.6)$ & $(.028)$ \\
\hline \multirow[t]{2}{*}{ Caucasian or A sian } & 12 & 21.8 & 2.2 & 46.3 & .400 \\
\hline & (5) & (3.1) & (1.5) & (37.4) & $(.032)$ \\
\hline \multirow[t]{2}{*}{ All Groups } & 239 & 19.3 & 2.1 & 33.4 & .389 \\
\hline & & $(2.0)$ & (1.7) & $(27.5)$ & $(.025)$ \\
\hline
\end{tabular}

Table II

Method of Recruitment among Study Participants, Beginning Year Two. New York City, 1995-1998

\begin{tabular}{lrr} 
M ethod of recruitment & N & $\%$ \\
Friend or relative & 91 & 55 \\
\hline Adolescent Health Center Health Educator & 54 & 32 \\
\hline Study Coordinator & 20 & 12 \\
\hline Adolescent Health Center Physician & 2 & 1 \\
\hline Total & 167 & 100
\end{tabular}

$\mathrm{p}=0.02$. Ferritin levels were also lower; however, the difference is not statistically significant. Using Pearson's correlation, there is no detectable relationship between ferritin levels and blood lead levels.

\section{Discussion}

Our study suggests that recruitment of adolescents for health-related studies can be enhanced through efforts to utilize non-traditional means, like "snow-ball" sampling. ${ }^{27}$ The majority of our participants have contacted us for participation after hearing about the study from a friend or relative. Few adolescents contacted the study coordinator directly after a visit to the AHC or responded to posters describing the study. Recruitment was enhanced by word of mouth by a trusted contact or through direct contact at the AHC by the study coordinator. Some selection bias could result if the women recruited by friends or relatives differ from the women who were recruited directly from the AHC; however, these women may also be more representative of the population at risk. Women attending the AHC may have better access to health care and different exposures compared to their friends and relatives who do not attend the AHC. This study demonstrates that enlisting the help of the participants themselves in addition to members of the health care community can enhance recruitment efforts substantially.

The women enrolled in our study have low current blood lead levels, similar to levels reported in NHANES III ${ }^{6}$ and other studies of urban women..$^{28}$ National surveys in the United States of blood lead continue to show that urban African-Americans have higher blood lead levels than Caucasians, despite the overall decline in lead exposure. The prevalence of elevated blood lead levels in African American children living in older housing has been reported at $21.9 \% .{ }^{29}$ However, to date we have found no statistically significant difference in blood lead between the ethnic groups in our study. This may reflect the low lead levels in general, as well as the relatively small number of Caucasians in our study. Many of the study participants reside in the New York City community of East Harlem. Current lead levels in New York City children reveal that rates of childhood lead poisoning in East Harlem rank $19^{\text {th }}$ out of 26 neighborhoods reported. ${ }^{30}$ Yet, in surveys in New York City during the 1970's, when children in this community had an average blood lead level of over $20 \mu \mathrm{g} / \mathrm{dl} .{ }^{31}$ Many of the participants from East Harlem live in housing that has undergone lead remediation and housing built more recently, 
which lessens household exposure. No study participants stated that they had had childhood lead poisoning. This may reflect uncertainty about their medical status as children, or may be due to the fact that there was no systematic testing for lead when they were young, or may be because none of them were lead poisoned. From a public health standpoint, our findings of low blood lead levels are encouraging. Although residents of this community had historically higher blood lead levels, current blood lead levels in this age group do not reflect this earlier exposure. Our analysis of bone lead measurements will address this issue.

Efforts to decrease lead exposure among urban minorities, such as increased public health awareness, remediation of lead-based paint and the routine testing of all children, appear to have been successful in East Harlem. With the bone lead data, we will have a better sense of: a) whether these young women differed in their long-term lead exposure, and $b$ ) whether they or their children could be at higher risk if bone lead is mobilized during pregnancy and lactation, as has been hypothesized.

In NHANES III, ${ }^{32}$ minority women of childbearing age were more likely to have iron deficiency anemia than Caucasians. In our study, we found that ferritin levels are lower in African-Americans than Hispanic or Caucasian women, but that these differences are not statistically significant. This may reflect the wide variability in normal values for ferritin. The normal clinical range in our laboratory is $10-140 \mathrm{ng} / \mathrm{ml}$. On the other hand, hematocrit measurements are significantly lower in African-American women in our study participants. This observation is consistent with many reports in which African Americans have been found to have lower hemoglobin and hematocrit levels. ${ }^{33}$ This lower hematocrit level is most likely due to other factors besides body iron stores, the causes for which are not well understood. At the blood lead levels seen in our study population, no inverse relationship is detectable between blood lead and iron stores. This again may be due to the low blood lead levels among these women and the fact that the majority of the women in the study are iron replete.

This study found that blood lead levels are low in young women of childbearing age in New York City. Efforts to decrease lead exposure in this high-risk group appear to have been successful. Future plans include the analysis of the baseline bone lead data collected, as well as analyses involving the repeated measures of blood lead, bone lead, ferritin, and hematocrit levels in participants who have had a child and their matched controls.

\section{Acknowledgements}

This work was supported by the Superfund Basic Research Program Grant P42 ES07384 from the National Institute of Environmental Health Sciences. This work was also supported in part by a grant (5 M01 RR0071) for the Mount Sinai General Clinical Research Center from the National Center for Research Resources, National Institutes of Health, and from Grant ES05697 from the National Institute of Environmental Health Sciences and by the Grant \#1 D43 TW00640 to the Mount Sinai/Queens College International Training Program in Environmental and Occupational Health by the Fogarty International Center of the United States National Institutes of Health.

\section{References}

1. Landrigan PJ.Toxicity of lead at low dose. Brit J Ind Med 1989;46:593596.

2. U nited States Environmental Protection A gency.Air quality criteria for lead. EPA report N 0. EPA-600/8-83/028aF-dF.4v. O ffice of Health and Environmental Assessment, Environmental $C$ riteria and Assessment 0 ffice, Research Triangle Park, N orth C arolina 1986.

3. N eedleman $\mathrm{HL}, \mathrm{G}$ unnoe C G, Leviton A,Allred EN .The long term effects of exposure to low doses of lead in childhood: An 11 year follow-up report. N Engl J Med 1990;322:83-88.

4. Bellinger $D$, Leviton A,W aterneux $C, N$ eedleman $H$, Rabinowitz M. Longitudinal analyses of prenatal and postnatal lead exposure and early cognitive development. N Engl J Med 1987;316:1037-1043.

5. M CMichael AJ, Baghurst PA,W igg N R,Vimpani GV, Robertson EF, Roberts RJ. Port Pirie Cohort Study: Environmental exposures to lead and children's abilities at the age of four years. N Engl J Med 1988;391: 468-475

6. Brody DJ, Pirkle JL, Kramer RA, Flegal KM, Matte TO, Gunter EW et al. Blood lead levels in the US population: Phase 1 of the Third $N$ ational Health and Nutrition Examination Survey (N HAN ES III, 1988; to 1991). JAMA 1994;272: 277-283.

7. Mahaffey KR, Annest JL, Roberts J, Murphy RS. N ational estimates of blood lead levels: U nited States 1976-1980:Association with selected demographic and socioeconomic factors. N Engl J Med 1982;307:573-579. 8. Mielke HW, Reagan PL. Soil is an important pathway of human lead exposure. Environ Health Perspect 1998;106 Suppl 1:217-229.

9. Centers for $D$ isease $C$ ontrol.Preventing lead poisoning in young children: a statement by the Centers for Disease Control.Atlanta,A:CDC 1991.

10. Bates MN, W yatt R, Garrett N. O Id paint removal and blood lead levels in children. NZ Med J 1997:110:373-377.

11. D hir H, Sharma A, Talukder G. Modifying effect of iron on lead-induced clastogenicity in mouse bone marrow cells. Biol Trace Elem Res 1992;34:279-286.

12. Barton JC, Conrad ME, Holland R. Iron, lead and cobalt absorption: Similarities and dissimilarities. Proc Soc Exp Biol Med 1981;166:64-69. 13. Marcus AH and Schwartz J. Dose-response curves for erythrocyte protoporphyrin vs. blood lead: Effect on iron status. Environ Res 1987;44: 221-227. 
14. Graziano JH, Popovac D, Factor-Litvak P et al. D eterminants of elevated blood lead during pregnancy in a population surrounding a lead smelter in Kosovo,Yugoslavia. Environ Health Perspect 1990;89:95-100. 15. C enters for D isease Control.Anemia during pregnancy in low-income women U nited States, 1987. Morb Mortal W kly Rep 1990;39:73-76.

16. Rabinowitz MD, W etherhill GW, Kopple JD. Kinetic analysis of lead metabolism in healthy humans.J C lin Invest 1976;58:260-270.

17. Bergdahl IA, Schutz A, Gerharrdsson L, Jensen A, Skerfving S. Lead concentrations in human plasma, urine and whole blood. Scand J Work Environ Health 1997;23:359-363.

18. Barry PS. A comparison of concentrations of lead in human tissues. Brit J Ind Med 1975;32:119-139.

19. Silbergeld EK, Schwartz J, Mahaffey K. Lead and osteoporosis: Mobilization of lead from bone in postmenopausal women. Environ Res 1988:47:79-94

20. Parsons P. Monitoring human exposure to lead:An assessment of current laboratory performances for the determination of blood lead. Environ Res 1992:57:149-162.

21. Miller DT, Paschal DC, G unter EW, Stroud PE, D 'Angelo J. D etermination of blood lead with electrothermal atomic absorption. Analyst 1987;112:1701-1704.

22. Snedecor GW, C ochran W G. Statistical Methods (7th ed.):A mes lowa, lowa State University Press, 1980.

23. SAS/STAT U ser's G uide (version 6). C ary, N C: SA S Institute, Inc. 1990. 24. US Department of C ommerce. US Census, 1990.

25. Pirkle JL, Brody DJ, Gunter EW, Kramer RA, Paschal DC, Flegal KM et al. The decline in blood lead levels in the United States: The $N$ ational
Health and Nutrition Examination Surveys (NHANES). JAMA 1994;272:284-291.

26. Kurtin D, Therrell BL Jr, Patterson P. D emographic risk factors associated with elevated lead levels in Texas children covered by Medicaid. Environ Health Perspect 1997;105(1):66-68.

27. Kelsey JL,Thompson W D, Evans AS. Methods in 0 bservational Epidemiology. N ew York: 0 xford University Press, 1986.

28. Hu H, Hashimoto D, Besser M. Levels of lead in blood and bone of women giving birth in a Boston hospital. Arch Environ Health 1996; 51: $52-58$.

29. Pirkle JL, Kaufmann RB, Brody DJ, Hickman T, Gunter EW, Paschal DC. Exposure of the U.S. population to lead, 1991-1994. Environ Health Perspect 1998;106:745-750.

30. Lead Poisoning Prevention Program, N ew York, N Y: N ew York City Department of Health. 1997.

31. Billick IH, Curran AS, Shier DR. Analysis of pediatric blood lead levels in N ew York City for 1970-1976. Environ Health Perspect 1979;31: 183-190.

32. Looker AC, Dallman PR, C arroll MD, Gunter EW, Johnson CL. Prevalence of iron deficiency in the United States. JAMA 1997;277:973-976.

33. Food and N utrition Board, Institute of Medicine. Iron deficiency anemia: Recommended guidelines for the prevention, detection and management among US children and women of childbearing age. Washington, DC: N ational A cademy Press, 1993. 